\title{
High-temperature-induced Electrolyte Leakage from Excised Leaves and Roots of Three Hollies
}

\author{
John M. Ruter ${ }^{1}$ \\ Coastal Plain Experiment Station, Department of Horticulture, University of \\ Georgia, Tifton, GA 31793
}

Additional index words. membrane thermostability, heat injury, Ilex aquifolium, Ilex cornuta

Abstract. Membrane thermostability of 'Needlepoint' Chinese holly (Ilex cornuta Lindl. \& Paxt.) , 'Albo-marginata' English holly (Ilex aquifolium L.), and 'Nellie R. Stevens', an Ilex aquifolium $\times$ Ilex cornuta hybrid, was determined by measuring electrolyte leakage in excised leaves and roots. The critical midpoint heat-killing temperature (T,) after a 30min exposure was $54.4 \pm 0.4 \mathrm{C}$ for 'Nellie $\mathrm{R}$. Stevens' leaves and was $\approx \mathrm{IC}$ higher than that for Chinese $(52.9 \pm 0.3 \mathrm{C})$ or English holly $(52.9 \pm 0.4 \mathrm{C})$. The $T_{\mathrm{m}}$ for English holly roots $(\mathbf{5 3 . 9}$ \pm 1.5C) was higher than that for either 'Nellie R. Stevens' $(51.7 \pm 0.3 \mathrm{C})$ or Chinese holly $(50.1 \pm 0.3 C)$. The results of this study suggest that English holly and 'Nellie R. Stevens' leaves and roots can withstand direct heat injury equal to or greater than that of Chinese holly.

Chinese hollies are heat and drought tolerant and are grown widely in the southeastern United States. English holly performs poorly in the southeastern United States (Dirr, 1990) and is difficult to find there in nurseries. However, the plant is grown successfully in the mountains of northern Georgia in cool, moist habitats (Midcap and Clay, 1989) that have conditions similar to those found in the plant's native European habitat. An Ilex aquifolium $\mathbf{x}$ Ilex cornuta hybrid, 'Nellie R. Stevens', is

\footnotetext{
Received for publication 24 Nov. 1992. Accepted for publication 12 Apr. 1993. We greatly appreciate the technical assistance of Bruce Tucker, statistical assistance of Ben Mullinix, and donation of plant material by Wight Nurseries. This research was funded in part by a grant from the Holly Society of America. Supported by state and Hatch funds allocated to the Georgia Agricultural Experiment Station. The cost of publishing this paper was defrayed in part by the payment of page charges. Under postal regulations, this paper therefore must be hereby marked advertisement solely to indicate this fact. Assistant Professor.
}

becoming one of the most popular landscape plants in the southern United States due to its vigorous growth and apparent heat tolerance. Chinese holly seems capable of contributing heat tolerance to hybrid plants (Pair, 1987; Ruter, 1993).

Foliar and root heat tolerance levels of many hollies grown in the southeastern United States have not been evaluated. Electrolyte leakage is an effective means of measuring membrane thermostability in leaves (Ahrens and Ingram, 1988) and roots (Ingram, 1986; Ingram and Buchanan, 1981; Ruter and Ingram, 1991). Loss of cell compartmentalization as a result of irreversible plasma membrane damage due to high temperatures has been documented in grapes (Vitis vinifera L.) (Abass and Rajashekar, 1991). The objective of my study was to determine the critical midpoint heat-killing temperature of leaves and roots of three landscape hollies grown in containers in the southeastern United States.

Plants were grown in 2.8-liter containers for 5 months in a shadehouse $(55 \%$ light exclusion) under natural daylength conditions at the Univ. of Georgia Coastal Plain Experiment Station in Tifton. The potting medium consistedof 4 milled pine bark : 1 sand $(\mathrm{v} / \mathrm{v})$ amended with Micromax (Grace-Sierra, Milpitas, Calif.) at $0.9 \mathrm{~kg}-\mathrm{m}$ " and Osmocote $18 \mathrm{~N}-2.6 \mathrm{P}-8.8 \mathrm{~K}$ (Grace-Sierra) applied as a topdressing at $1.5 \mathrm{~kg} \mathrm{~N} / \mathrm{m}^{3}$.

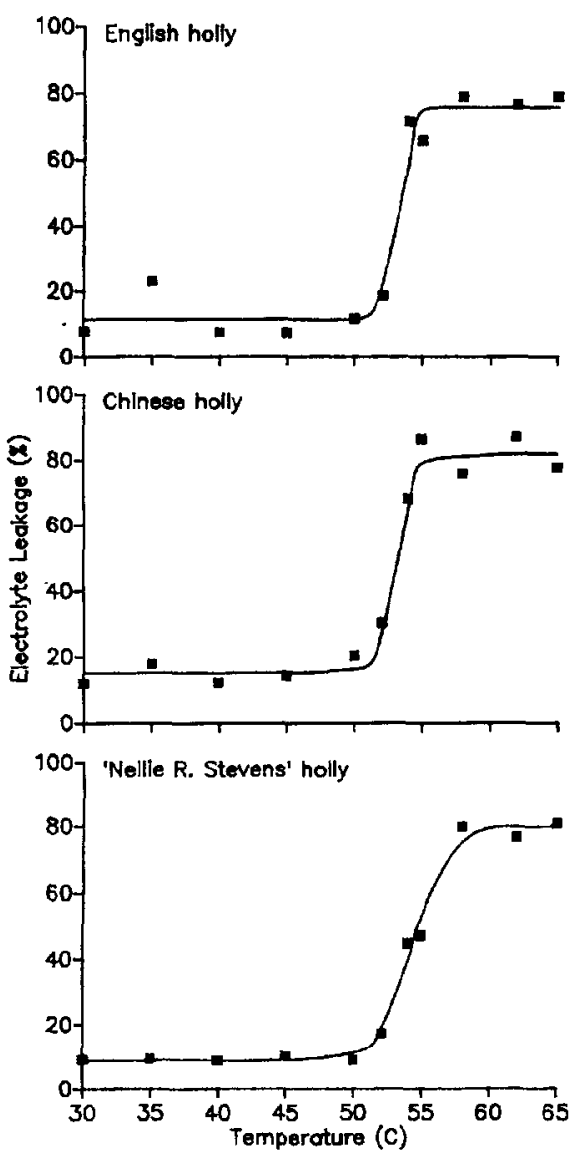

Fig. 1. Electrolyte leakage from foliage $(n=8)$ of 'Albo-marginata' English holly, 'Needlepoint' Chinese holly, and 'Nellie R. Stevens'. The critical midpoint heat-killing temperatures $\left(T_{m}\right)$ \pm SE for English, Chinese, and 'Nellie R. Stevens' hollies were $52.9 \pm 0.4 \mathrm{C}, 52.9 \pm 0.3 \mathrm{C}$, and 54.4 $\pm 0.4 \mathrm{C}$, respectively. Sigmoidal response curves were fitted to electrolyte leakage data using a least-squares approach. 
Electrolyte leakage procedures for determining a critical midpoint heat-killing temperature for fully expanded whole leaves from current-season's growth were modified from Ahrens and Ingram (1988). Leaves were rinsed lightly with deionized water and placed in test tubes with loosely fitted screw caps. One leaf and $1 \mathrm{ml}$ of deionized water were added to each tube. Samples were placed randomly in a thermostatically controlled circulating water bath for $30 \mathrm{~min}$, with temperatures ranging from 30 to $65 \mathrm{C}$ (eight samples per temperature). After $30 \mathrm{~min}$, leaves were removed from the test tubes, cut into 5-mm strips perpendicular to the long axis of the leaf, and returned to the test tubes with $20 \mathrm{ml}$ of deionized water. Samples were incubated in ice for $24 \mathrm{~h}$ before initial electrical conductivity was determined. Final electrical conductivity readings were

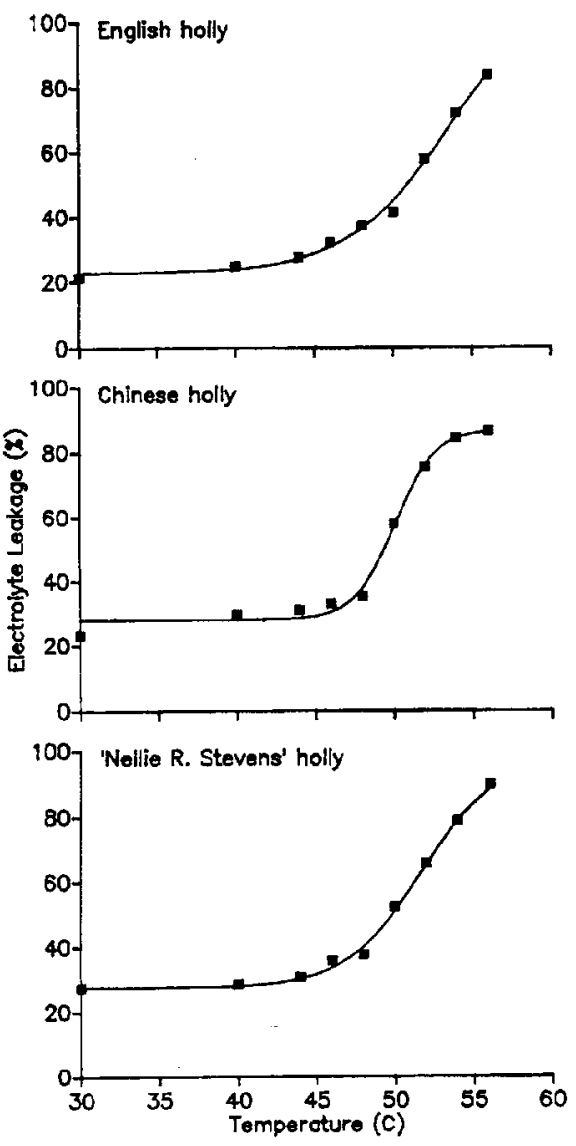

Fig. 2. Electrolyte leakage from excised roots of 'Albo-marginata' English holly $(n=4)$, 'Needlepoint' Chinese holly ( $\mathrm{n}=8$ ), and 'Nellie R. Stevens' holly $(\mathrm{n}=8)$. The critical midpoint heat-killing temperatures $\left(T_{m}\right) \pm S E$ for English. Chinese, and 'Nellie R. Stevens' hollies were $53.9 \pm 1.5 \mathrm{C}, 50.1 \pm 0.3 \mathrm{C}$, and $51.7 \pm 0.3 \mathrm{C}$, respectively. Sigmoidal response curves were fitted to electrolyte leakage data using a least-squares approach. taken on initial samples after autoclaving them for $20 \mathrm{~min}$ at $121 \mathrm{C}$ and $202.6 \mathrm{kPa}$ and incubating them in ice for $24 \mathrm{~h}$. Electrolyte leakage was expressed as the ratio of incubation solution conductivity after treatment to the conductivity after autoclaving. Critical midpoint heat-killing temperatures were determined using a sigmoidal response curve fitted to electrolyte leakage data across temperature treatments using a least-squares approach (Ingram and Buchanan, 1984).

Electrolyte leakage procedures for determining the $\mathrm{T}_{\mathrm{m}}$ for roots of the three hollies were performed as described by Ingram and Buchanan (1981). Excised portions (0.5-g samples) taken from the terminal 15 to $20 \mathrm{~cm}$ of actively growing roots were placed in test tubes and exposed for $30 \mathrm{~min}$ to temperatures ranging from 30 to $56 \mathrm{C}$ in a thermostatically controlled circulating water bath. After removal, roots were cut into $10-\mathrm{mm}$ segments and returned to the test tubes with $20 \mathrm{ml}$ of deionized water before ice bath incubation for $24 \mathrm{~h}$. After initial electrical conductivity was read, root samples were autoclaved as previously described and incubated in ice for $24 \mathrm{~h}$ before final electrical conductivity was measured. Expression of electrolyte leakage and determination of $\mathrm{T}_{\mathrm{m}}$ were the same as for leaves.

Electrolyte leakage from whole leaves followed sigmoidal response curves (Fig. 1) similar to those found by others (Ahrens and Ingram, 1988). The $T_{\mathrm{m}}$ for 'Nellie R. Stevens' leaves $(54.4 \pm 0.4 \mathrm{C})$ was $\approx 1 \mathrm{C}$ higher than that for English $(52.9 \pm 0.4 \mathrm{C})$ or Chinese holly $(52.9 \pm$ $0.3 \mathrm{C}$ ). Under landscape conditions during summer, canopy temperatures in hybrid hollies have been shown to exceed 50C for short periods during the day (Pair and Still, 1982).

Electrolyte leakage from excised roots also followed sigmoidal response curves (Fig. 2), a result similar to that of work with other holly roots (Ingram, 1986; Ingram and Buchanan, 1981; Ruter and Ingram, 1991). English holly had a higher root $\mathrm{T}_{\mathrm{m}}(53.9 \pm 1.5 \mathrm{C})$ than either 'Nellie R. Stevens' $(51.7 \pm 0.3 \mathrm{C})$ or Chinese holly $(50.1 \pm 0.3 \mathrm{C})$. Excised 'Burfordii' (Ilex cornuta $\mathrm{L}$.) roots had a $\mathrm{T}_{\mathrm{m}}$ of $46.5 \pm 0.5 \mathrm{C}$ (Ingram and Buchanan, 1981).

The results of this study indicate that the poor performance of English holly in the southeastern United States probably is not due to direct membrane injury by exposure to supraoptimal temperatures.

Native to northwestern Europe, English holly generally is found as an understory shrub where it is protected from exposure to high temperatures (Peterken and Lloyd, 1967). English holly does not prosper where soil temperatures are elevated (Bauers, 1990). Temperatures as high as $58 \mathrm{C}$ have been recorded in container media (Martin and Ingram, 1988), while 40C may prevail for several hours (Ingram, 1981). A 10-min exposure of 'Rotundifolia' Japanese holly (Ilex crenata Thunb.) roots to 46C damaged root respiratory mechanisms (Ruter and Ingram, 1991), whereas exposure of root zones at $>38 \mathrm{C}$ for 3 weeks altered plant $\mathrm{C}$ balance and increased root membrane leakage (Ruter and Ingram, 1990).

While the roots of Chinese holly had a lower $\mathrm{T}_{\mathrm{m}}$ than those of English holly after a short exposure to high temperatures, Chinese holly and 'Nellie R. Stevens' may be more tolerant of long-term environmental stresses. Further work on water relations and plant $\mathrm{C}$ balances are needed to understand the adaptability of hollies to the southeastern United States.

\section{Literature Cited}

Abass, M. and C.B. Rajashekar. 1991. Characterization of heat injury in grapes using ${ }^{1} \mathrm{H}$ nuclear magnetic resonance methods. Plant Physiol. 96:957-961.

Ahrens, M.J. and D.L. Ingram. 1988. Heattolerance of citrus leaves. HortScience 24:747-748.

Bauers, B.M. 1990. Holly hotline. Holly Soc. J. 8(4):8. Dirr, M.A. 1990. Manual of woody landscape plants. Stipes Publishing Co., Champaign, Ill.

Ingram, D.L. 1981. Characterization of temperature fluctuations and woody plant growth in white polybags and conventional black containers. HortScience 16:762-763.

Ingram, D.L. 1986. Root cell membrane heat tolerance of two dwarf hollies. J. Amer. Soc. Hort. Sci. 111:270-272.

Ingram, D.L. and D.W. Buchanan. 1981. Measurement of direct heat injury of roots of three woody plants. HortScience 16:769-771.

Ingram, D.L. and D.W. Buchanan. 1984. Lethal high temperatures for roots of three citrus rootstocks. J. Amer. Soc. Hort. Sci. 109:189-193.

Martin, C.A. and D.L. Ingram. 1988. Temperature dynamics in black poly containers. Proc. Southern Nurserymen's Assn. Res. Conf. 33:71-74.

Midcap, J.T. and H. Clay. 1989. Hollies for Georgia homeowners. Georgia Agr. Expt. Sta. Publ. B-664.

Pair, J.C. 1987. Winter hardiness, leaf water potential, and heat tolerance of 'China Girl' holly as affected by landscape exposure. HortScience 22:268-270.

Pair, J.C. and SM. Still. 1982. Growth, hardiness, and leaf water potential of blue holly (Ilex $x$ meserveae) cultivars affected by exposure. HortScience 17:823-825.

Peterken, G.F. and P.S. Lloyd. 1967. Biological flora of the British isles: Ilex aquifolium L. J. Ecol. 55:841-851.

Ruter, J.M. 1993. Foliar heat tolerance of two hybrid hollies. HortScience 28:650-652.

Ruter, J.M. and D.L. Ingram. 1990. ${ }^{14}$ Carbon-labelled photosynthate partitioning in Ilex crenata 'Rotundifolia' at supraoptimal root-zone temperatures. J. Amer. Soc. Hort. Sci. 115:1008-1013.

Ruter, J.M. and D.L. Ingram. 1991. The effect of supraoptimal temperatures on root respiratory characteristics of 'Rotundifolia' holly. J. Amer. Soc. Hort. Sci. 116:560-564. 